\title{
Antioxidant Activity of Porcine Skin Gelatin Hydrolyzed by Pepsin and Pancreatin
}

\author{
Oun Ki Chang ${ }^{1}$, Go Eun Ha ${ }^{1,2}$, Seok-Geun Jeong ${ }^{1}$, Kuk-Hwan Seol ${ }^{1}$, Mi-Hwa Oh${ }^{1}$, Dong Wook Kim³ \\ Aera Jang ${ }^{3}$, Sae Hun Kim², Beom-Young Park', and Jun-Sang Ham ${ }^{1 *}$ \\ ${ }^{1}$ Animal Products and Development Division, National Institute of Animal Science, \\ Rural Development Administration, Suwon 441-706, Korea \\ ${ }^{2}$ Department of Food Bioscience and Technology, Korea University, Seoul 136-701, Korea \\ ${ }^{3}$ Department of Animal Products and Food Science, Kangwon National University, Chuncheon 200-701, Korea
}

\begin{abstract}
Gelatin is a collagen-containing thermohydrolytic substance commonly incorporated in cosmetic and pharmaceutical products. This study investigated the antioxidant activity of gelatin by using different reagents, such as 2,2-azinobis-(3-ethylbenzothiazoline-6-sulfonic acid) (ABTS), 2,2-di (4-tert-octylphenyl)-1-picrylhydrazyl (DPPH), and oxygen radical absorbance capacity-fluorescein (ORAC-FL) in a porcine gelatin hydrolysate obtained using gastrointestinal enzymes. Electrophoretic analysis of the gelatin hydrolysis products showed extensive degradation by pepsin and pancreatin, resulting in an increase in the peptide concentration $(12.1 \mathrm{mg} / \mathrm{mL})$. Antioxidant activity, as measured by ABTS, exhibited the highest values after 48 -h incubation with pancreatin treatment after pepsin digestion. Similar effects were observed at $48 \mathrm{~h}$ incubation, that is, $61.5 \%$ for the DPPH assay and $69.3 \%$ for the ABTS assay. However, the gallic acid equivalent (GE) at $48 \mathrm{~h}$ was 87.8 $\mu \mathrm{M}$, whereas 14.5 $\mu \mathrm{M}$ GE was obtained using the ABTS and DPPH assays, indicating about sixfold increase. In the ORACFL assay, antioxidant activity corresponding to $45.7 \mu \mathrm{M}$ of trolox equivalent was found in the gelatin hydrolysate after $24 \mathrm{~h}$ hydrolysis with pancreatin treatment after pepsin digestion, whereas this activity decreased at $48 \mathrm{~h}$. These antioxidant assay results showed that digestion of gelatin by gastrointestinal enzymes prevents oxidative damage.
\end{abstract}

Key words: antioxidant activity, gelatin, pepsin, pancreatin, hydrolysis

\section{Introduction}

Several studies have shown that reactive oxygen species and free radicals cause a wide range of conditions such as cancer, DNA damage, diabetes, inflammation, cardiovascular diseases due to hypertension, allergies, and aging (Calabrese et al., 2005; Je et al., 2004; Kullisaar et al., 2003). Artificial antioxidants such as butylated hydroxyanisole (BHA) and butylated hydroxytoluene (BHT) have been used to preserve food products by delaying discoloration and deterioration due to oxidation ( $\mathrm{Li}$ et al., 2007). However, the use of antioxidants as food additives has been limited due to their potential health hazards (Becker, 1993; Giménez et al., 2009), and the defence

\footnotetext{
*Corresponding author: Jun Sang Ham, Animal Products and Development Division, National Institute of Animal Science, Rural Development Administration, Suwon 441-706, Korea. Tel: 82-31-290-1696, Fax: 82-31-290-1697, E-mail: hamjs@, korea.kr
}

systems of organisms are generally incapable of preventing oxidative damage (Kullisaar et al., 2003). Thus, natural antioxidants in food should be screened to prevent development of disease and to reduce free radical activity and oxidative stress (Giménez et al., 2009).

Gelatin is a water-soluble protein compound obtained from thermohydrolysis of collagen. It is also an essential protein component of the body, as well as a common ingredient in various cosmetic and pharmaceutical products. Two types of gelatin are commonly produced, based on the pretreatment procedure employed. Type-A gelatin is derived by acidic hydrolysis of porcine skin, whereas type-B gelatin is generated by basic hydrolysis of cattle bone and cattle hide. Type-A gelatin production involves pretreatment within a $\mathrm{pH}$ range of 3.8-6.0 and a $\mathrm{pHi}$ range of 6-8, and type-B gelatin production involves pretreatment within a $\mathrm{pH}$ range of 5.7-7.4 and a $\mathrm{pH}$ range of 4.7-5.3 (Singh et al., 2002).

The protein content in gelatin mainly consists of glycine $(25.5 \%)$, proline $(18.0 \%)$, and hydroxyproline $(14.1 \%)$ 
(Singh et al., 2002). The protein sequence is composed of a triplet peptide, which is glycine- $\mathrm{X}-\mathrm{Y}$, in which $\mathrm{X}$ is predominantly a proline residue and $\mathrm{Y}$ is usually a hydroxyproline residue (Cole, 2000). Except for elastin, which occurs at very low concentrations, gelatin usually contains the hydroxyproline residue.

A recent study has shown that gelatin is used in food processing as an emulsifier, foaming agent, colloid stabilizer, biodegradable film-forming material, and microencapsulating agent (Gómez-Guillén et al., 2011). An increasing number of studies have described the use of bioactive peptides from food proteins such as milk proteins, casein and whey (Hernández-Ledesma et al., 2005; Korhonen, 2009; Miguel et al., 2009), egg protein (Samaraweera et al., 2011; Wellman-Labadie et al., 2008), and soybean (de Mejia and de Lumen, 2006; Rho et al., 2009). In addition, the use of collagen or gelatin peptides obtained from various animals through enzymatic treatment has increased based on their bioactive properties related to antimicrobial, antioxidant, and antihypertensive activities (Gómez-Guillén et al., 2011).

Collagen is difficult to hydrolyze using most proteases and thus requires the action of collagenases for its enzymatic hydrolysis. However, gelatin is more susceptible to most proteases, such as trypsin, chymotrypsin, pepsin, alcalase, properase E, pronase, bromelain, and papain (Cole, 2000; Kim et al., 2001; Lin and Li, 2006; Mendis et al., 2005; Yang et al., 2008).

Among the gelatin sources, we chose porcine skin gelatin for study based on its high gelatin content (46\%); gastrointestinal enzymes were used as proteases for digestion. Thus, the objective of the present study was to investigate the antioxidant properties of porcine gelatin hydrolysate obtained using gastrointestinal enzymes.

\section{Materials and Methods}

\section{Reagents and materials}

Chemical reagents and molecules such as 2,2-azinobis(3-ethylbenzothiazoline-6-sulfonic acid) (ABTS, A1888), 2,2-di (4-tert-octylphenyl)-1-picrylhydrazyl (DPPH, D9132), gallic acid, and 6-hydroxy-2,5,7,8-tetramethylchroman-2carboxylic acid (Trolox) were purchased from Sigma Aldrich (USA). Gastrointestinal enzymes such as pepsin and pancreatin (P-1750, containing trypsin, amylase and lipase) were also procured from Sigma Aldrich (USA). Oxygen radical absorbance capacity-fluorescein (ORAC-FL) was obtained from Cell Biolabs, Inc. (USA). The other chemicals used in this study were of analytical grade. Gelatin was provided by Geltech Co. Ltd. (Korea).

\section{Electrophoresis}

Sodium dodecyl sulphate-polyacrylamide gel electrophoresis (SDS-PAGE) was performed as previously described by Chang et al. (2013b), using a 5\% acrylamide stacking gel and 15\% acrylamide separating gel. After migration, the gel was stained and destained by previously described method (Chang et al., 2012)

\section{Gelatin hydrolysis}

Gelatin was provided by Geltech Co. Ltd, (Korea) and directly utilized for hydrolysis by gastrointestinal enzymes such as pepsin and pancreatin. The gelatin substrate was prepared at a concentration of $5 \mathrm{mg} / \mathrm{mL}$ in distilled water. The enzyme used in this study included $0.1 \mathrm{~N} \mathrm{HCl}$ for pepsin (pH 2.0) and $50 \mathrm{mM}$ sodium phosphate buffer $(\mathrm{pH}$ 8.0) for pancreatin. The enzyme to substrate ratios were $1 / 1$ for pepsin and $1 / 5$ for pancreatin. The gelatin was first treated with pepsin for $3 \mathrm{~h}$ and then subsequently digested by pancreatin for $24 \mathrm{~h}$ and $48 \mathrm{~h}$. The reaction mixtures were incubated at $37^{\circ} \mathrm{C}$. The hydrolysis reaction was terminated by immersing the reaction mixture in boiling water for $5 \mathrm{~min}$. An aliquot was immediately retrieved at each incubation time ( $3 \mathrm{~h}$ for pepsin and 24 and $48 \mathrm{~h}$ for pancreatin). Samples were filtrated through $0.45-\mu \mathrm{m}$ filters (GE Healthcare, Pittsburgh, PA, USA) and stored at $-20^{\circ} \mathrm{C}$.

\section{Peptide quantification}

To measure peptide content, we used a previously described method (Cho, 2009; Church et al., 1983; Frister et al., 1988; Minervini et al., 2003) involving ortho-phtalaldehyde (OPA, Sigma, USA), with a slight modification. The OPA solution contained dithiothreitol (DTT; Sigma, USA) dissolved in ethanol. The sodium tetraborate decahydrate buffer (100 mM final concentration) containing $0.2 \mathrm{~g}$ of SDS was prepared in $150 \mathrm{~mL}$ of distilled water. The 2 solutions were mixed, and the final volume of the solution was adjusted to $200 \mathrm{~mL}$ using distilled water. Bacto tryptone (Difco, USA) at various concentrations (0.25-1.5 $\mathrm{mg} / \mathrm{mL})$ was used as a standard. Leucine $(0.1 \mathrm{mg} / \mathrm{mL})$ was selected as a control. Each $20 \mu \mathrm{L}$ of sample was added to $200 \mu \mathrm{L}$ of the OPA reagent in 96-well clear flat-bottomed microplate (SPL, Korea). After the reaction mixture was agitated 3 times, it was incubated at $37^{\circ} \mathrm{C}$ for $3 \mathrm{~min}$ to accelerate the reaction involving OPA and the sample. The absorbance was measured at $340 \mathrm{~nm}$ by using a microplate reader (Molecular Devices, USA). All assays were 
carried out in triplicate.

\section{Antioxidant activity: ABTS radical-scavenging assay}

The free radical-scavenging activity of the gelatin hydrolysates was determined using the 2,2-azino-bis-(3-ethylbenzothiazoline-6-sulfonic acid) $\left(\mathrm{ABTS}^{+\cdot}\right)$ radical cation (Sigma-Aldrich, USA), according to a previously described method by Chang et al. (2003b) and Re et al. (1999). After preparation of ABTS solution $16 \mathrm{~h}$ in the dark at room temperature, the $\mathrm{ABTS}^{+\cdot}$ radical solution was adjusted to be $0.70 \pm 0.02$ at $734 \mathrm{~nm}$ using spectrophotometer (Molecular Devices, USA). The reaction mixture was composed of $50 \mu \mathrm{L}$ and $950 \mu \mathrm{L}$ of the $\mathrm{ABTS}^{+\cdot}$ radical solution. The absorbance was measured at $734 \mathrm{~nm}$ after $10 \mathrm{~min}$ of incubation at $30^{\circ} \mathrm{C}$. All the assays were conducted in triplicate. Gallic acid (Sigma-Aldrich, USA) was selected to perform a standard curve. The antioxidantscavenging activity of gelatin and its hydrolysates was expressed as a percent as follows: scavenging activity $(\%)=$ $\left\{\left(\mathrm{A}_{\text {control }}-\mathrm{A}_{\text {sample }}\right) / \mathrm{A}_{\text {control }}\right\} \times 100$, in which $\mathrm{A}_{\text {control }}$ represents the ABTS absorbance of distilled water and expressed also as ìmoles gallic acid equivalent (GE), calculated from the equation of the standard curve based on gallic acid (Chang et al., 2013a; Kim et al., 2013).

\section{Antioxidant activity: DPPH radical-scavenging assay}

Another method, 2,2-di (4-tert-octylphenyl)-1-picrylhydrazyl (DPPH, Sigma-Aldrich, USA) was also used to antioxidant activity test. The DPPH assay was performed according to a previously described method (Kim et al., 2013; Madhujith et al., 2006). The DPPH solution prepared in methanol was mixed with an equal volume of sample in a 96-well clear flat-bottomed microplate (SPL, Korea) and placed in the dark for $30 \mathrm{~min}$. The absorbance was measured at $517 \mathrm{~nm}$ by using a microplate reader (Molecular Devices, USA). Gallic acid (Sigma-Aldrich, USA) was selected to perform a standard curve. All the assays were carried out in triplicate. The antioxidantscavenging activity of gelatin and its hydrolysates was expressed as a percent as follows: scavenging activity $(\%)=\left\{1-\left[\left(\mathrm{A}_{\text {sample }}-\mathrm{A}_{\text {blank }}\right) / \mathrm{A}_{\text {control }}\right]\right\} \times 100$, in which $\mathrm{A}_{\text {con- }}$ trol represents the initial DPPH absorbance and $A_{\text {blank }}$ represents methanol absorbance. The radical-scavenging activity was also calculated from the equation of the standard curve based on gallic acid and expressed in terms of $\mu$ moles GE.

\section{Antioxidant Activity: ORAC-FL assay}

The ORAC assay kit (Cell Biolabs, Inc., USA) based on the method by Ou et al. (2001) and Dávalos et al. (2004) was used to investigate antioxidant activity, following the manufacturer's instructions. The reaction was performed in 96-well black with clear flat-bottom polystyrene not treated microplate without lid, nonsterile (Corning, USA), using trolox $(0,2.5,5,10,20,30,40$, and $50 \mu \mathrm{M})$ as the standard. Twenty-five microliters of each sample was loaded into each well of the 96-well plate, followed by $150 \mu \mathrm{L}$ of fluorescein. After the reaction mixture was mixed, it was incubated at $37^{\circ} \mathrm{C}$ for $30 \mathrm{~min}$. Then, $25 \mu \mathrm{L}$ of the free radical initiator solution was added to each well by using a multichannel pipette. The plate was automatically shaken. Fluorescence was recorded using a fluorometric microplate reader (Molecular Devices, USA) at $37^{\circ} \mathrm{C}$ with excitation and emission wavelengths of 480 and $520 \mathrm{~nm}$, respectively, at 2-min intervals for $60 \mathrm{~min}$. All the assays were conducted in triplicate. A blank assay that did not include any antioxidants was also performed. The area under the curve (AUC) was calculated for each sample and standard using the final assay values and the linear regression formula below. The AUC can be calculated using the following equation: $\mathrm{AUC}=1+\mathrm{RFU}_{2} /$ $\mathrm{RFU}_{0}$ to $\mathrm{RFU}_{60} / \mathrm{RFU}_{0}$, in which $\mathrm{RFU}_{0}$ is the relative fluorescence value at time point 0 and $R F U_{x}$ represents the relative fluorescence value of time point $\mathrm{X}$ (e.g., $\mathrm{RFU}_{2}$ is the relative fluorescence value at $2 \mathrm{~min}$ ). The net AUC was calculated by subtracting the blank from the AUC of each sample. The final ORAC-FL values have been expressed as micromoles of trolox equivalent (TE).

\section{Statistical analysis}

Data were analysed by ANOVA followed by Duncan's multiple range test using the Statistical Analysis System Software (SAS version 9.13, SAS Institute, Cary, NC). Significant differences were set at a $5 \%$ level $(p<0.05)$.

\section{Results and Discussion}

Hydrolysis of gelatin obtained from pig skin collagen using gastrointestinal enzymes was accomplished using a 2-step hydrolysis reaction. The first step was hydrolysis by pepsin at $\mathrm{pH} 2$ at $37^{\circ} \mathrm{C}$ for $3 \mathrm{~h}$, whereas the second step was the successive hydrolysis by pancreatin at $\mathrm{pH} 8$ at $37^{\circ} \mathrm{C}$ for 24 and $48 \mathrm{~h}$. The reason selected these conditions was to apply the enough protein digestion time in gastrointestinal tract (Chang et al., 2006). Therefore, the digestion was sufficiently carried out as that of Li et al. (2007). These gelatin hydrolysates were used to determine the antioxidant activity using the ABTS, DPPH, and 
ORAC assays.

\section{Electrophoretic pattern and peptide production of gelatin hydrolysates}

Electrophoresis was performed to verify the hydrolysis of gelatin with the gastrointestinal enzymes, pepsin and pancreatin. Gelatin was prepared in a $0.1 \%(\mathrm{v} / \mathrm{v})$ acetic acid solution. As shown in Fig. 1, it was degraded well by the gastrointestinal enzymes. The gelatin used in present study showed the typical type I collagen, with a molecular weight range of $45-200 \mathrm{kDa}$ as previously study reported by Kim et al. (2013). Gelatin hydrolysis with pepsin for $3 \mathrm{~h}$ resulted in hydrolysis of most of the protein. The gelatin was further degraded by pancreatin treatment for 24 and $48 \mathrm{~h}$.

The concentration of the peptides hydrolyzed was expressed in terms of $\mathrm{mg} / \mathrm{mL}$ of bactotryptone (casein hydrolysate generated by trypsin) by a standard curve equation using OPA at various concentrations. Based on the electrophoretic pattern, the peptide concentration was generally similar, despite a slight increase after pancreatin treatment, which corresponded to $7.2,7.6$, and $8.0 \mathrm{mg} /$ $\mathrm{mL}$ of tryptone for pepsin for $3 \mathrm{~h}$, pepsin plus pancreatin treatment for $24 \mathrm{~h}$ and pepsin plus pancreatin treatment for $48 \mathrm{~h}$, respectively (Fig. 2). The results for the gelatin used in the present study were similar to those for porcine skin powder containing gelatin in a study by Kim et al.

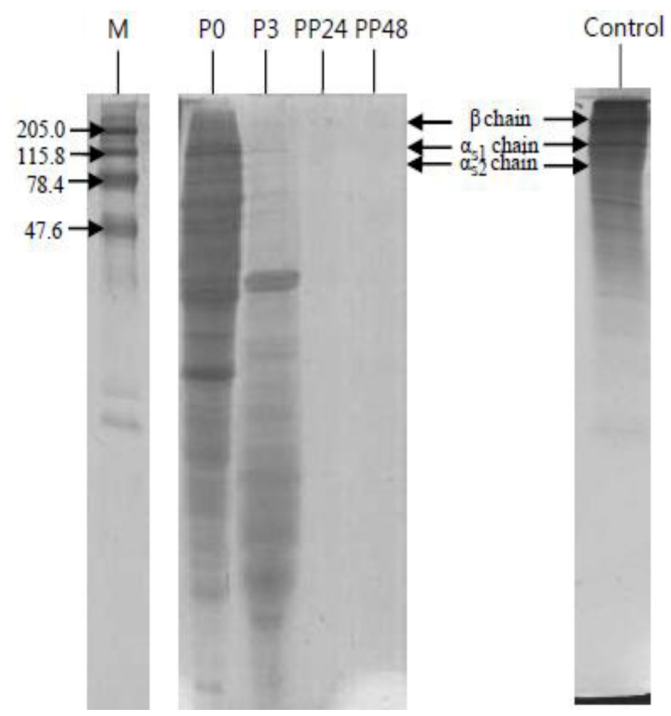

Fig. 1. Electrophoretic analysis of gelatin treated by gastrointestinal enzymes during incubation. Lane M: Protein standard marker, P0: $0 \mathrm{~h}$ incubation with pepsin, P3: $3 \mathrm{~h}$ incubation with pepsin. PP24: $24 \mathrm{~h}$ incubation with pancreatin after $3 \mathrm{~h}$ of pepsin treatment, PP48: $48 \mathrm{~h}$ incubation with pancreatin after $3 \mathrm{~h}$ of pepsin treatment, Control: gelatin with non-enzyme treatment.
(2013).

\section{Investigation of antioxidant activity of gelatin hydro- lysates}

\section{ABTS assay}

The ABTS assay used in the present study for investigating the free radical-scavenging properties of gelatin hydrolysates obtained using gastrointestinal enzymes was adapted from a previously described method (Re et al., 1999) that is widely used for studying free radical-scavenging properties with respect to antioxidant activity.

The effect of radical scavenging with gelatin hydrolyzed using pepsin or pancreatin increased with reaction time (Table 1). Although the hydrolysate obtained using pepsin showed a relatively low activity, the antioxidant activity of gelatin hydrolyzed by pepsin increased by $16.9 \%$ compared to that of the control (3.1\%). Further hydrolysis using pancreatin induced greater pepsin activity and their activities were $53.2 \%$ and $69.3 \%$, corresponding to 66.5 and $87.8 \mu \mathrm{M}$ of GE for 24 and $48 \mathrm{~h}$ of hydrolysis, respectively. Therefore, gelatin could be used as a natural substance during ingestion. Our results are consistent with those of previous studies (Kim et al., 2013) that showed that low molecular weight pig skin gelatin hydrolysates obtained using flavourzyme had higher activity than pig skin powder. To support this result, we employed other assays such as DPPH and ORAC.

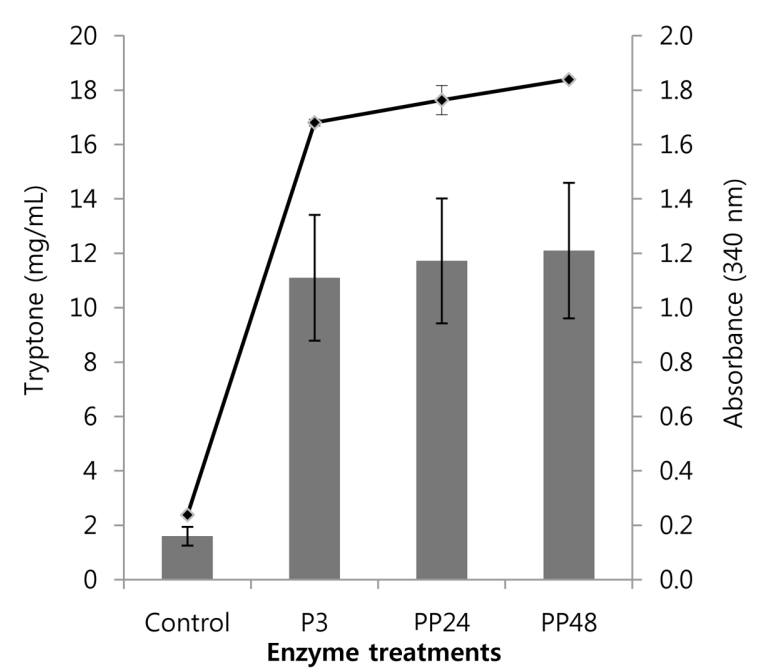

Fig. 2. Peptide concentration obtained using the OPA method of gelatin hydrolysis with gastrointestinal enzymes. Bar chart: Tryptone $(\mathrm{mg} / \mathrm{mL})$, Line chart: Absorbance at $340 \mathrm{~nm}$. Control: gelatin with non-enzyme treatment, P3: 3 h incubation with pepsin. PP24: 24 h incubation with pancreatin after $3 \mathrm{~h}$ of pepsin treatment, PP48: $48 \mathrm{~h}$ incubation with pancreatin after $3 \mathrm{~h}$ of pepsin treatment. 
Table 1. Antioxidant activities of gelatin hydrolysates after gastrointestinal enzyme treatments at various incubation times with the ABTS assay

\begin{tabular}{ccccc}
\hline \hline \multirow{2}{*}{ ABTS } & \multirow{2}{*}{ Control } & Pepsin & \multicolumn{2}{c}{ Pancreatin } \\
\cline { 3 - 5 } & $0.680 \pm 0.01^{\mathrm{a}}$ & $0.583 \pm 0.01^{\mathrm{b}}$ & $0.329 \pm 0.00^{\mathrm{c}}$ & $0.216 \pm 0.00^{\mathrm{d}}$ \\
\hline $\mathrm{A}_{735}$ & 3.1 & 16.9 & 53.2 & 69.3 \\
$\%^{\mathrm{e}}$ & 0.0 & 18.4 & 66.5 & 87.8 \\
$\mathrm{GE}^{\mathrm{f}}$ & & $\mathrm{P} 3$ & \\
\hline
\end{tabular}

Control: gelatin with non-enzyme treatment, P3: $3 \mathrm{~h}$ incubation with pepsin. PP24: $24 \mathrm{~h}$ incubation with pancreatin after $3 \mathrm{~h}$ of pepsin treatment, PP48: $48 \mathrm{~h}$ incubation with pancreatin after $3 \mathrm{~h}$ of pepsin treatment. All the assays were conducted in triplicate.

${ }^{\text {a-d }}$ Mean \pm Standard deviation values in rows show statistically significant differences in Duncan's multiple range test $(p<0.05)$.

${ }^{\mathrm{e}}$ Antioxidant activity $(\%)=\left\{\left(\mathrm{A}_{\text {control }}-\mathrm{A}_{\text {sample }}\right) / \mathrm{A}_{\text {control }}\right\} \times 100$, in which $\mathrm{A}_{\text {control }}$ represents the initial ABTS absorbance of distilled water.

${ }^{\mathrm{f}}$ The radical-scavenging activity was also calculated from the equation of the standard curve, based on gallic acid, and expressed in terms of $\mu$ moles GE based on the equation of Chang et al., 2013b).

\section{DPPH assay}

The DPPH assay for free radical-scavenging activity was selected to confirm the high ABTS activity. This assay has also been widely used because of its simple procedure (Que et al., 2006). Similar to the results for ABTS activity, DPPH radical-scavenging activity increased with enzyme treatment (Table 2). The activity was $16.7 \%, 59.6 \%$, and $61.5 \%$ for each enzyme, pepsin for $3 \mathrm{~h}$, pepsin plus pancreatin treatment for $24 \mathrm{~h}$ and pepsin plus pancreatin treatment for $48 \mathrm{~h}$, respectively. Unlike our result, DPPH activity from porcine collagen hydrolysate showed the low activity as a $13.4 \%$ for pepsin treatment during $24 \mathrm{~h}$ and showed $27.0 \%$ for successive pancreatin treatment after pepsin during $24 \mathrm{~h}$ (Li et al., 2007). Another study was also similar (Ao and $\mathrm{Li}, 2012$ ). They reported that the antioxidant activity showed $12.5 \%$ by pepsin treatment for $24 \mathrm{~h}$ and about $22 \%$ by pancreatin treatment for $24 \mathrm{~h}$ after pepsin for $24 \mathrm{~h}$.

On the other hand, DPPH activity of gelatin hydrolysates in this study was similar to those for ABTS activity (Table 2). A difference was observed between the GE values for DPPH and ABTS activity. Although the DPPH activity, which has been expressed in terms of percentage, was as high as the ABTS activity, the GE values for the
ABTS assay were at least 4 or 5 fold higher than those for DPPH activity. The GE values of DPPH activity corresponded to $4.8,14.1$, and $14.5 \mu \mathrm{M}$, respectively. The higher radical-scavenging activities for the ABTS assay compared to those for the DPPH assay in the present study may be attributable to the type of sample, which consists of either hydrophobic or hydrophilic compounds. Similar results have been reported by Kim et al. (2013), in which higher activity was observed using the ABST assay compared to that obtained using DPPH. It is possible to detect not only the hydrogen-donating antioxidant but also chainbreaking antioxidant activity and to measure both of the water- and oil-soluble phases in the ABTS assay compared to the DPPH method. Thus, although the DPPH method allows simple and rapid measurement of radical-scavenging activity, the limitations may also be observed with respect to colour interference and sample solubility (Oboh et al., 2010).

\section{ORAC assay}

The ORAC assay is a classic tool for measuring the oxygen radical absorbance capacity of an antioxidant. This method is highly sensitive and accurate in detecting oxygen radicals in various compounds, food, and other bio-

Table 2. Antioxidant activities of gelatin hydrolysates after gastrointestinal enzyme treatment at various incubation times using the DPPH assay

\begin{tabular}{ccccc}
\hline \hline \multirow{2}{*}{ DPPH } & \multirow{2}{*}{ Control } & Pepsin & \multicolumn{2}{c}{ Pancreatin } \\
\cline { 3 - 5 } & & P3 & PP24 & $0.190 \pm 0.01^{\mathrm{c}}$ \\
\hline $\mathrm{A}_{517}$ & $0.317 \pm 0.01^{\mathrm{a}}$ & $0.347 \pm 0.01^{\mathrm{b}}$ & $0.00^{\mathrm{d}}$ & 61.5 \\
$\%^{\mathrm{e}}$ & 24.9 & 16.7 & 59.6 & 14.1 \\
$\mathrm{GE}^{\mathrm{f}}$ & 6.5 & 4.8 & 14.5 \\
\hline
\end{tabular}

Control: gelatin with non-enzyme treatment, P3: $3 \mathrm{~h}$ incubation with pepsin. PP24: $24 \mathrm{~h}$ incubation with pancreatin after $3 \mathrm{~h}$ of pepsin treatment, PP48: $48 \mathrm{~h}$ incubation with pancreatin after $3 \mathrm{~h}$ of pepsin treatment. All the assays were conducted in triplicate.

${ }^{\mathrm{a}-\mathrm{d}}$ Mean \pm Standard deviation values in rows show statistically significant differences in Duncan's multiple range test $(p<0.05)$.

${ }^{e}$ DPPH assay $(\%)=\left\{1-\left[\left(\mathrm{A}_{\text {sample }}-\mathrm{A}_{\text {blank }}\right) / \mathrm{A}_{\text {control }}\right]\right\} \times 100$, in which $\mathrm{A}_{\text {control }}$ represents DPPH absorbance of distilled water. $\mathrm{A}_{\text {blank }}$ represents methanol absorbance.

${ }^{\mathrm{f}}$ The radical-scavenging activity was also calculated from the equation of the standard curve, based on gallic acid, and expressed in terms of $\mu$ moles GE $\left(y=4.6278 x+1.1967, \mathrm{R}^{2}=0.9861\right)$. 
Table 3. Antioxidant activities of gelatin hydrolysates after gastrointestinal enzyme treatments at various incubation times using the ORAC-FL assay

\begin{tabular}{ccccc}
\hline \hline \multirow{2}{*}{ ORAC } & \multirow{2}{*}{ Control } & Pepsin & \multicolumn{2}{c}{ Pancreatin } \\
\cline { 2 - 5 } & & P3 & PP24 & PP48 \\
\hline Fluorescence $^{\mathrm{e}}$ & $5.426 \pm 0.21^{\mathrm{a}}$ & $8.414 \pm 0.05^{\mathrm{b}}$ & $15.991 \pm 0.58^{\mathrm{c}}$ & $12.749 \pm 1.02^{\mathrm{d}}$ \\
Net AUC $^{\mathrm{d}}$ & 0 & 2.7 & 10.3 & 7.0 \\
TE & 0 & 12.3 & 45.7 & 31.4 \\
\hline
\end{tabular}

Control: gelatin with non-enzyme treatment, P3: $3 \mathrm{~h}$ incubation with pepsin. PP24: $24 \mathrm{~h}$ incubation with pancreatin after $3 \mathrm{~h}$ of pepsin treatment, PP48: $48 \mathrm{~h}$ incubation with pancreatin after $3 \mathrm{~h}$ of pepsin treatment. All the assays were conducted in triplicate.

${ }^{\mathrm{a}-\mathrm{d}}$ Mean \pm Standard deviation values in rows show statistically significant differences in Duncan's multiple range test $(p<0.05)$.

${ }^{\mathrm{e}}$ Excitation $480 \mathrm{~nm}$ and emission $520 \mathrm{~nm}$.

${ }^{\mathrm{f}} \mathrm{AUC}$ (Area Under Curve) $=1+\mathrm{RFU}_{2} / \mathrm{RFU}_{0}$ to $\mathrm{RFU}_{60} / \mathrm{RFU}_{0}$, in which $\mathrm{RFU}_{0}$ is the relative fluorescence value at time point 0 and $\mathrm{RFU}_{\mathrm{x}}$ represents the relative fluorescence value at time point $\mathrm{X}$ (e.g., $\mathrm{RFU}_{2}$ is the relative fluorescence value at 2 min). The net AUC was calculated by subtracting the blank from the AUC of each sample measured in triplicate. The final ORAC-FL values were expressed as micromoles of TE. $y=0.2269 x-0.0855, R^{2}=0.9984$.

logical samples (Prior et al., 2003). In the present study, various concentrations of trolox, which is a water-soluble derivative of vitamin $\mathrm{E}$, were used as the standard. The antioxidant activity, as measured using the ORAC-FL kit, showed a $12.3 \mu \mathrm{M}$ TE value after pepsin treatment, which increased $24 \mathrm{~h}$ after subsequent treatment with pancreatin. Unlike the ABTS results, the highest antioxidant activity was observed after $24 \mathrm{~h}$ of incubation with pancreatin treatment after pepsin digestion. The concentration corresponding to trolox was $45.7 \mu \mathrm{M}$ (Table 3). The decrease in antioxidant activity at $48 \mathrm{~h}$ may be attributable to peptides generated by gastrointestinal enzymes being hydrolyzed into smaller peptides, thus inducing lower antioxidant activity. In contrast, the antioxidant activity measured using the ABTS or DPPH tool increased or was of the same value until $48 \mathrm{~h}$. This observation may be attributable to differences in the methods used to detect the antioxidant compounds in gastrointestinal hydrolysates.

Because these three tools widely use to determine the antioxidant activity in food protein (Ao and Li, 2012; Li et al., 2007; Nimalaratne et al., 2011), the use of these tools in present study is suitable to detect the antioxidant activity in gelatin hydrolysates obtained by pepsin and pancreatin treatment. Therefore, if the antioxidant activity in gelatin hydrolysate through these tools is present, it indicates that gelatin hdyrolysate has an antioxidant activity. As for ABTS assay, the antioxidant allows the reduction of pre-formed radical $\mathrm{ABTS}^{+\cdot}$ generated by oxidation of ABTS after reaction of the potassium persulfate. Therefore, if the concentration of the antioxidant in sample is high, the reduction will be increased (Re et al., 1999) indicating that the radical scavenging effect is present. In the case of DPPH assay (Mark and Alger, 1997), it shows the similar mechanism to that of ABTS assay for antioxidant activity. Regarding ORAC assay which is based on the oxi- dation of a fluorescent probe by peroxyl radicals, the antioxidants in samples can block the peroxyl radical oxidation of the fluorescent probe until the antioxidant activity in the sample is exhausted (Dávalos et al., 2004; Ou et al., 2001).

In these results, the gelatin protein hydrolysates may contain peptides which have the hydrophobic amino acid residues on the sequence. The hydrophobic amino acid including aromatic amino acid (Sarmadi and Ismail, 2010) can increase the radical scavenging activity (Rajapakse $e t$ al., 2005). Ren et al. (2008) have been also reported that basic peptides had greater capacity to scavenge hydroxyl radical than acidic or neutral peptides.

\section{Conclusions}

This study investigated the antioxidant activity of hydrolysates in porcine gelatin by using the ABTS, DPPH, and ORAC-FL assays. High antioxidant activity was observed $24 \mathrm{~h}$ after gastrointestinal enzyme treatment. The results of this study showed that the hydrolyzed gelatin during digestion could be used as a natural antioxidant substance (or peptide) to prevent oxidative damage. However, further studies on the isolation and identification of the antioxidant peptide using MS analysis and similar analytical tools are warranted.

\section{Acknowledgements}

The author, Oun Ki Chang, is a post-doctoral researcher in 2013 Post-Doctoral Fellowships project of the National Institute of Animal Science, Rural Development Administration, Republic of Korea. This work supported by a grant (PJ00858502) of the National Institute of Animal Science. 


\section{References}

1. Ao, J. and Li, B. (2012) Amino acid composition and antioxidant activities of hydrolysates and peptide fractions from porcine collagen. Food Sci. Technol. Int. 18, 425-434.

2. Becker, G. L. (1993) Preserving food and health: Antioxidants make functional, nutritious preservatives. Food Processing 12, 54-56.

3. Calabrese, V., Lodi, R., Tonon, C., D’Agata, V., Sapienza, M., Scapagnini, G., Mangiameli, A., Pennisi, G., Giuffrida Stella, A. M., and Butterfield, D. A. (2005) Oxidative stress, mitochondrial dysfunction and cellular stress response in Friedrich's ataxia. J. Neurological Sci. 233, 145-162.

4. Chang, O. K., Humbert, G., Gaillard, J. L., and Lee, B. O. (2006) Characterization of equine milk and cheese making. Korean J. Food Sci. An. 26, 368-374.

5. Chang, O. K., Perrin, C., Galia, W., Saulnier, F., Miclo, L., Roux, E., Driou, A., Humbert, G., and Dary, A. (2012) Release of the cell-envelope protease PrtS in the growth medium of Streptococcus thermophilus 4F44. Int. Dairy J. 23, 91-98.

6. Chang, O. K., Ha, G. E., Han, K. S., Seol, K. H., Kim, H. W., Jeong, S. G., Oh, M. H., Park, B. Y., and Ham, H. S. (2013a). Novel antioxidant peptide derived from the ultrafiltrate of ovomucin hydrolysate. J. Agri. Food Chem. 61, 7294-7300.

7. Chang, O. K., Seol, K. H., Jeong, S. G., Oh, M. H., Park, B. Y., Perrin, C., and Ham, J. S. (2013b) Casein hydrolysis by Bifidobacterium longum KACC91563 and antioxidant activities of peptides derived therefrom. J. Dairy. Sci. DOI: 10. 3168/jds.2013-6687

8. Cho, Y. (2009) Comparative study of lactic acid bacteria for antioxidative and casein phosphopeptide-producing activities. Graduate School, Chonnam National University, Korea.

9. Church, F. C., Swaisgood, H. E., Porter, D. H., and Catignani, G. L. (1983) Spectrophotometric assay using $o$-phthaldialdehyde for determination of proteolysis in milk and isolated milk proteins. J. Dairy Sci. 66, 1219-1227.

10. Cole, C. G. B. (2000) Gelatin. In: Encyclopedia of Food Science and Technology. Francis, F. J. (ed) John Wiley \& Sons, New York, pp. 1183-1188.

11. Dávalos, A., Miguel, M., Bartolome, B., and Lopez-Fandiño, R. (2004) Antioxidant activity of peptides derived from egg white proteins by enzymatic hydrolysis. J. Food Protect. 67, 1939-1944.

12. de Mejia, E. and de Lumen, B. O. (2006) Soybean bioactive peptides: A new horizon in preventing chronic diseases. Sexuality, Reproduction \& Menopause 4, 91-95.

13. Frister, H., Meisel, H., and Schlimme, E. (1988) OPA method modified by use of N,N-dimethyl-2-mercaptoethylammonium chloride as thiol component. Fresenius' J. Anal. Chem. 330, 631-633.

14. Giménez, B., Alemán, A., Montero, P., and Gómez-Guillén, M. C. (2009) Antioxidant and functional properties of gelatin hydrolysates obtained from skin of sole and squid. Food Chem. 114, 976-983.

15. Gómez-Guillén, M. C., Giménez, B., López-Caballero, M. E., and Montero. M. P. (2011) Functional and bioactive proper- ties of collagen and gelatin from alternative sources: A review. Food Hydrocolloid. 25, 1813-1827.

16. Hernández-Ledesma, B., Dávalos, A., Bartolomé, B., and Amigo, L. (2005) Preparation of antioxidant enzymatic hydrolysates from $\alpha$-lactalbumin and $\beta$-lactoglobulin. identification of active peptides by HPLC-MS/MS. J. Agric. Food Chem. 53, 588-593.

17. Je, J. Y., Park, P. J., and Kim, S. K. (2004). Free radical scavenging properties of hetero-chitooligosaccharides using an ESR spectroscopy. Food Chem. Toxicol.42, 381-387.

18. Kim, D. W., Park, K., Ha, G. E., Jung, J. R., Chang, O. K., Ham, J. S., Jeong, S. G., Park, B. Y., Song, J., and Jang, A. (2013) Anti-oxidative and neuroprotective activities of pig skin gelatin hydrolysates. Korean J. Food Sci. An. 33, 258-267.

19. Kim, S., Kim, Y., Byun, H., Nam, K., Joo, D., and Shahidi, F. (2001) Isolation and characterization of antioxidative peptides from gelatin hydrolysate of Alaska Pollack skin. J. Agric. Food Chem. 49, 1984-1989.

20. Korhonen, H. (2009) Milk-derived bioactive peptides: From science to applications. J. Funct. Foods 1, 177-187.

21. Kullisaar, T., Songisepp, E., Mikelsaar, M., Zilmer, K., Vihalemm, T., and Zilmer, M. (2003) Antioxidative probiotic fermented goats' milk decreases oxidative stress-mediated atherogenicity in human subjects. British J. Nutr. 90, 449-456.

22. Li, B., Chen, F., Wang, X., Ji, B., and Wu, Y. (2007) Isolation and identification of antioxidative peptides from porcine collagen hydrolysate by consecutive chromatography and electrospray ionization-mass spectrometry. Food Chem. 102, 11351143.

23. Lin, L. and Li, B. (2006) Radical scavenging properties of protein hydrolysates from Jumbo flying squid (Dosidicus eschrichitii Steenstrup) skin gelatin. J. Sci. Food Agric. 86, 22902295.

24. Madhujith, T., Izydorczyk, M., and Shahidi, F. (2006) Antioxidant properties of pearled barley fractions. J. Agric. Food Chem. 54, 3283-3289.

25. Mark, S. and Alger, M. (1997) Polymer science dictionary. Springer. p. 152.

26. Mendis, E., Rajapakse, N., Byun, H., and Kim, S. (2005) Investigation of jumbo squid (Dosidicus gigas) skin gelatin peptides for their in vitro antioxidant effects. Life Sci. 77, 21662178.

27. Miguel, M., Contreras, M. M., Recio, I., and Aleixandre, A. (2009) ACE-inhibitory and antihypertensive properties of a bovine casein hydrolysate. Food Chem. 112, 211-214.

28. Minervini, F., Algaron, F., Rizzello, C. G., Fox, P. F., Monnet, V., and Gobbetti, M. (2003) Angiotensin I-converting-enzymeinhibitory and antibacterial peptides from Lactobacillus helveticus PR4 proteinase-hydrolyzed caseins of milk from six species. Appl. Environ. Microbiol. 69, 5297-5305.

29. Nimalaratne, C., Lopes-Lutz, D., Schieber, A., and Wu, J. (2011) Free aromatic amino acids in egg yolk show antioxidant properties. Food Chem. 129, 155-161.

30. Oboh, G., Adefegha, S. A., Ademosun, A. O., and Unu, D. (2010) Effects of hot water treatment on the phenolic photochemicals and antioxidant activities of lemon grass (Cymbo- 
pogon itratus). Electron. J. Environ. Agric. Food Chem. 9, 503-513.

31. Ou, B., Hampsch-Woodill, M., and Prior, R. L. (2001) Development and validation of an improved oxygen radical absorbance capacity assay using fluorescein as the fluorescent probe. J. Agric. Food Chem. 49, 4619-4626.

32. Prior, R. L., Hoang, H., Gu, L., Wu, X., Bacchiocca, M., Howard, L., Hampsch-Woodill, M., Huang, D., Ou, B., and Jacob, R. (2003) Assays for hydrophilic and lipophilic antioxidant capacity (oxygen radical absorbance capacity (ORACFL)) of plasma and other biological and food samples. J. Agric. Food Chem. 51, 3273-3279.

33. Que, F., Mao, L., Zhu, C., and Xie, G. (2006) Antioxidant properties of Chinese yellow wine, its concentrate and volatiles. LWT-Food Sci. Technol. 39, 111-117.

34. Rajapakse, N., Mendis, E., Jung, W. K., Je, J. Y., and Kim, S. K. (2005) Purification of a radical scavenging peptide from fermented mussel sauce and its antioxidant properties. Food Res. Int. 38, 175-182.

35. Re, R., Pellegrini, N., Proteggente, A., Pannala, A., Yang, M., and Rice-Evans, C. (1999) Antioxidant activity applying an improved ABTS radical cation decolorization assay. Free Radic. Biol.Med. 26, 1231-1237.

36. Ren, J., Zhao, M., Shi, J., Wang, J., Jiang, Y., Cui, C., Kakuda, Y., and Xue, S. J. (2008) Purification and identification of anti- oxidant peptides from grass carp muscle hydrolysates by consecutive chromatography and electrospray ionization-mass spectrometry. Food Chem. 108, 727-736.

37. Rho, S. J., Lee, J. S., Chung, Y. I., Kim, Y. W., and Lee, H. G. (2009) Purification and identification of an angiotensin I-converting enzyme inhibitory peptide from fermented soybean extract. Proc. Biochem. 44, 490-493.

38. Samaraweera, H., Zhang, W. G., Lee E. J., and Ahn, D. U. (2011) Egg yolk phosvitin and functional phosphopeptidesreview. J. Food Sci. 76, 143-150.

39. Sarmadi, B. H. and Ismail, A. (2010) Antioxidative peptides from food proteins: A review. Peptides. 31, 1949-1956.

40. Singh, S., Rao, K. V. Rama., Venugopal, K., and Manikandan, R. (2002) Alteration in dissolution characteristics of gelatincontaining formulations: A review of the problem, test methods, and solutions. Pharmaceutical Technol. 26, 36-58.

41. Wellman-Labadie, O., Picman, J., and Hincke, M. T. (2008) Comparative antibacterial activity of avian egg white protein extracts. Br. Poult. Sci. 49, 125-132.

42. Yang, J., Ho, H., Chu, Y., and Chow, C. (2008) Characteristic and antioxidant activity of retorted gelatin hydrolysates from cobia (Rachycentron canadum) skin. Food Chem. 110, 128136.

(Received 2013.6.30/Revised 2013.8.5/Accepted 2013.8.9) 